\title{
Population growth of three freshwater prawns (Macrobrachium spp.) in Lower Ogun River, Southwest Nigeria
}

\author{
A. S. YAKUB \\ Department of Biological Oceanography, Nigerian Institute for Oceanography and Marine Research, PMB \\ 12729, No. 3, Wilmot Point Road, Bar Beach, Victoria Island, Lagos, Nigeria. \\ Tel.: 234-08035653960,E-mail: demolaniomr@yahoo.com
}

\begin{abstract}
Growth parameters of the populations of three freshwater prawns: Macrobrachium vollenhovenii, M. macrobrachion and M. felicinum in the Lower Ogun River were determined. For each population, lengthfrequency data for twenty-four month period (January 2006-December 2007) were analysed to determine the growth parameters, using routines in FAO-ICLARM Stock Assessment Tools (FISAT II). Estimates from FISAT indicated steady growth of the three populations. M. vollenhovenii had mean maximum length $\left(\mathrm{L}_{\max }\right)$, asymptotic length $(\mathrm{L} \infty)$, performance index ( $\left.\varnothing^{\prime}\right)$ and growth coefficient $(\mathrm{K})$ of $187.00 \mathrm{~mm} \pm 5.66,215.10 \mathrm{~mm} \pm$ $16.27,3.98 \pm 0.04$ and $0.2 \pm 0.04$ respectively. Mean values for $\mathrm{L}_{\max }, \mathrm{L} \infty, \varnothing^{\prime}$ and $\mathrm{K}$ for $M$. macrobrachion were $86.00 \mathrm{~mm} \pm 1.00,100.26 \mathrm{~mm} \pm 12.20,0.59 \pm 0.16$ and $3.76 \pm 0.01$ respectively, while $76.45 \pm 3.25,69.00 \mathrm{~mm}$ $\pm 1.00,1.33 \pm 0.67$ and $3.87 \pm 0.19$ were the respective mean values of the growth parameters for M. felicinum. The suitability of the Macrobrachium species for aquaculture based on the estimated growth parameters is discussed.
\end{abstract}

(C) 2010 International Formulae Group. All rights reserved.

Keywords: Lower Ogun River, Asymptotic length, Maximum length, Growth performance index, Growth coefficient.

\section{INTRODUCTION}

Freshwater prawns (of the genus Macrobrachium) constitute a group of economically important macroinvertebrate fauna. They support tremendous artisanal and capture prawn fisheries activities both in the coastal and inland water bodies in Nigeria and other tropical and subtropical countries (Abowei et al., 2006; Abohweyere 2008; Abohweyere et al., 2008).

Study of growth is an important aspect of stock assessment, which is very crucial for sustainable exploitation and management of aquatic macrofauna resources. Growth parameters, especially determined through the use of length frequency distribution data give account of the state of populations of aquatic macrofauna in the tropical region (Ansa and Sikoki, 2006). Moreover, apart from being the major inputs into stock prediction models, growth parameters also indicate the suitability of aquatic macrofauna species for aquaculture (Abowei et al., 2006; Ansa and Sikoki, 2006; Francis and Sikoki, 2006).

Although, stock assessment studies of some species of Macrobrachium and some other shellfishes in Nigerian water bodies have been carried out using length frequency data such as Enin (1995), Ansa and Sikoki (2006), Nwosu and Wolfi (2006), Abohweyere (2008), and Abohweyere et al. (2008), on a general note there is a dearth of information on the stock assessment of shrimps and prawns in Nigeria and other tropical nations (Abowei et al., 2006). Meanwhile, Gayanilo et al. (2005) advocated the use of length-frequency distribution data for the assessment of tropical shellfish stocks.

Therefore, this paper reports on the growth parameters of three species of 
Macrobrachium: $M$. vollenhovenii, $M$. macrobrachion and M. felicinum in the Lower Ogun River, Southwest Nigeria where the prawns are often harvested by artisan fishers. Apart from serving as useful tools for sustainable and effective management of the resources, the findings in this study will also reveal the suitability of the prawns for aquaculture.

\section{MATERIALS AND METHODS \\ Study area}

The study was carried out in Ishasi area of lower course of Ogun River. The entire study area lies on Longitude $3^{\circ} 16^{\prime} \mathrm{E}$ and Latitude of between $6^{\circ} 37^{\prime} \mathrm{N}$ and $6^{\circ} 39^{\prime} \mathrm{N}$ (Figure 1). The area has a tropical rainforest climatic condition with rainy season from April through November and dry season from December through March. The mid-channel of Lower Ogun River is more or less devoid of higher macrophytes, while the vegetation towards the bank ranged from floating higher plants such as duckweed (Lemna spp.), water lettuce (Pistia) and water hyacinth (Echhiornia crassipes) and rooted plants such as Elephant grass (Pennisetum), Giant star grass (Cynodon) and Bamboo (Bambusa).

Artisanal fishing activities both for finfish and freshwater prawns, Marobrachium were the major human activities observed in the study area. Perturbations are kept to the barest minimum within the study area probably due to the fact that the neighbouring community depends on the river for source of water for domestic use.

\section{Sample collection}

Samples of Macrobrachium prawns were collected from three stations (stations 1, 2 and 3) with $200 \mathrm{~m}$ intervals (Figure 1) on monthly basis.

At each station prawns were collected from both left and right sides of the river bank using a scooping gear made of $0.5 \mathrm{~m}$ diameter circular mosquitoe net bag as described by Udolisa and Solarin (1979) and Marioghae (1990). Identification of various species of Macrobrachium prawns collected was done using diagnostic features described by Powell (1983) and Marioghae (1982).

Total length (TL) of every prawn specimen was measured orbital notch to the tip of the telson (Abohweyere et al., 2008) to the nearest $0.01 \mathrm{~mm}$ using Vernier callipers. The TL values were used to generate monthly length-frequency data for each of the three Macrobrachium prawns of each station.

\section{Data analysis}

For each of the three Macrobrachium species, data from the three stations were pooled to generate length-frequency data for each of the years 2006 and 2007.

The length-frequency data were analysed to determine the growth parameters of each Macrobrachium species using routines in a computer software programme, FAOICLARM Stock Assessment Tools (FISAT II), (Gayanilo et al., 2005).

Asymptotic length $(\mathrm{L} \infty)$ for each year was estimated through Powell-Wetherall plot (Powell, 1979; Wetherall, 1986). Lœ was seeded into ELEFAN I routine to scan for the best growth coefficient $(\mathrm{K})$ value (Ansa and Sikoki, 2006). The growth performance index $(\varnothing)$ was determined using $\mathrm{L} \infty$ and $\mathrm{K}$ values as follows:

$\varnothing^{\prime}=2 \log \mathrm{L} \infty+\log \mathrm{K}$ (Abohweyere, 2008)

Maximum length $\left(\mathrm{L}_{\max }\right)$ was obtained by direct observation

Mean and standard deviation values for $\mathrm{L} \infty, \varnothing^{\prime}, \mathrm{K}$, and $\mathrm{L}_{\max }$ of each Macrobrachium species were estimated.

\section{RESULTS AND DISCUSSION}

Mean maximum lengths $\left(\mathrm{L}_{\max }\right)$ of $187.00 \pm 5.66 \mathrm{~mm}, \quad 86.00 \pm 1.00 \mathrm{~mm}$ and $69.00 \pm 1.00 \mathrm{~mm}$ were respectively recorded for M. vollenhovenii, M. macrobrachion and M. felicinum while the Powell-Wetherall plot gave mean asymptotic lengths $(\mathrm{L} \infty)$ of $215.10 \pm 16.27 \mathrm{~mm}, \quad 100.26 \pm 12.20 \mathrm{~mm}$ and $76.45 \pm 3.25 \mathrm{~mm}$ for the prawns respectively (Table 1). The variations within the $\mathrm{L}_{\max }$ and L $\infty$ for the three species are indicative to differences in maximum attainable size of various species of Macrobrachium. Marioghae (1990) recorded similar variations in the maximum attainable size for the three species in Lagos Lagoon. Also, Willfuhr-Nast et al. (1993) that cited M. vollenhovenii as the main targeted prawn species in the West African tropical water bodies attributed it to its much larger attainable size than others. The $\mathrm{L}_{\max }$ values for $M$. vollenhovenii and $M$. macrobrachion, which decreased from 2006 


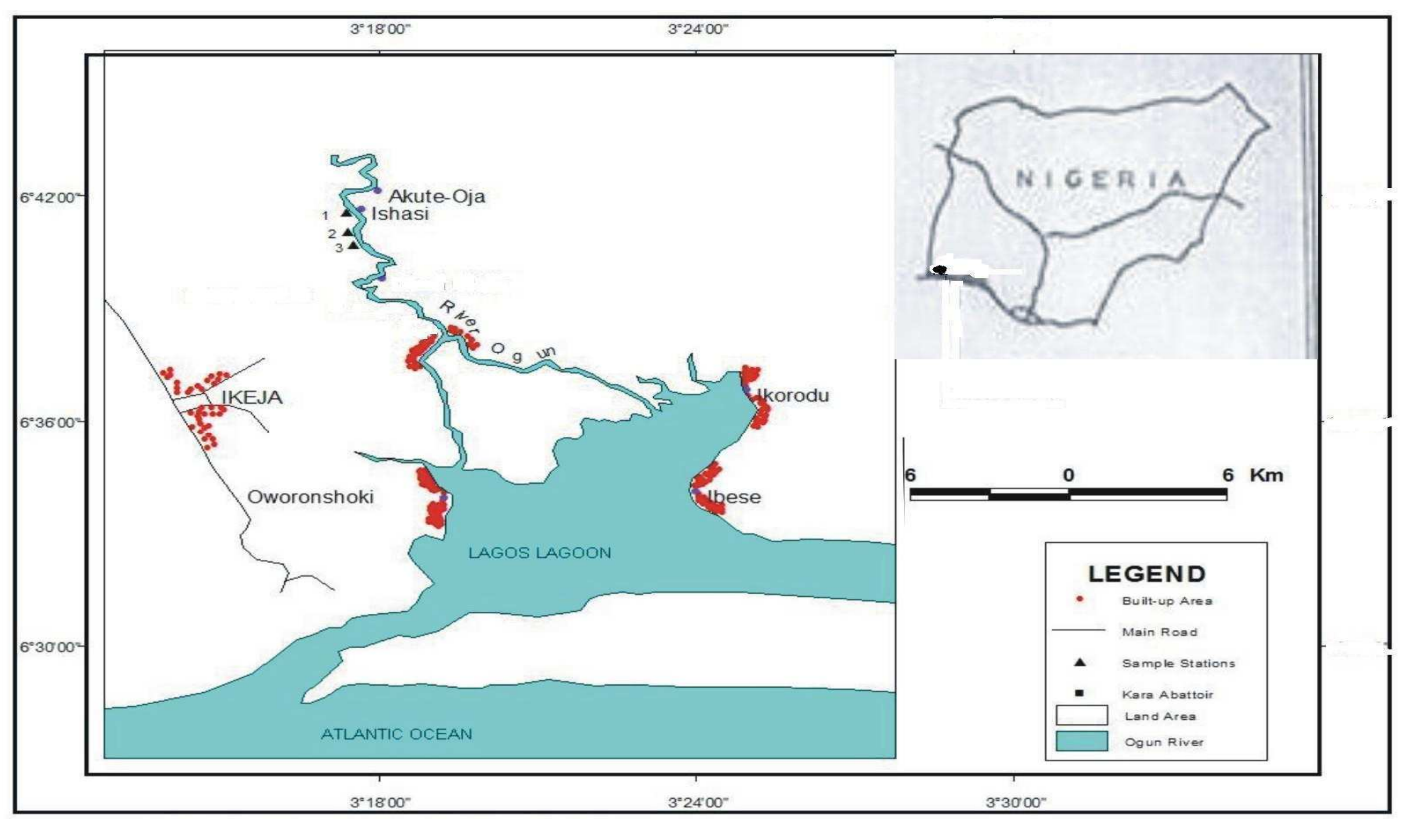

Figure 1: Map showing location of Lower Ogun River (study area) in Nigeria and the designated sampling stations.

to 2007 (Table 1), could be as a result of removal of large individuals from the environment probably due to fishing (Ansa and Sikoki, 2006).

The mean $\mathrm{L} \infty$ for $M$. vollenhovenii is higher than $164 \mathrm{~mm}, 180 \mathrm{~mm}$ and $188.10 \mathrm{~mm}$ respectively recorded for the species by Gabche and Hockey (1995) from Lobe River, Cameroon, Etim and Sankare (1998) from Fahe Reservoir, Cote'divore and Abowheyere et al. (2008) from Lagos-Lekki Lagoon, but comparable to $213 \mathrm{~mm}$ obtained by Nwosu and Wolfi (2006) for the species from Cross River Estuary, southern Nigeria. The asymptotic length, L $\infty$ also known as length at infinity, is a major parameter in evaluating the status of the population of aquatic macrofauna (Abowheyere, 2008). Thus, the relatively high L $\infty$ recorded for $M$. vollenhovenii in this study is indicative to a better status of the population of the species in the current study area than those studied by the earlier workers. This could be as a result of differences in geographical locations and prevailing ecological conditions of the areas.
Growth performance index ( $\left.\varnothing^{\prime}\right)$ values for the three species did not fluctuate much from 2006 to 2007 (Table 1) and indicated a steady growth of the prawns. Mean values of $\emptyset$ ' for $M$. vollenhovenii, M. macrobrachion and $M$. felicinum were $3.98 \pm 0.04,3.76 \pm$ 0.01 and $3.87 \pm 0.19$ respectively (Table 1 ). These values are higher than 2.50 and 2.3 reported for $M$. vollenhovenii and $M$. macrobrachion respectively in Lagos-Lekki Lagoon by Abowheyere (2008) and Abowheyere et al. (2008) as well 2.48 recorded by Enin (1995) for $M$. macrobrachion in Cross River Estuary. The relatively high $\varnothing$ values recorded in this study indicates that Lower Ogun River supports a more steady growth of Macrobrachium populations than the areas studied by the earlier workers.

Mean growth coefficient $(\mathrm{K})$ values of $0.2 \pm 0.04,0.59 \pm 0.16$ and $1.33 \pm 0.67$ were recorded for $M$. vollenhovenii, $M$. macrobrachion and $M$. felicinum respectively (Table 1). Higher K value (0.55) was however 
Table 1: Growth parameters of three species of freshwater prawn (Macrobrachium) in Lower Ogun River

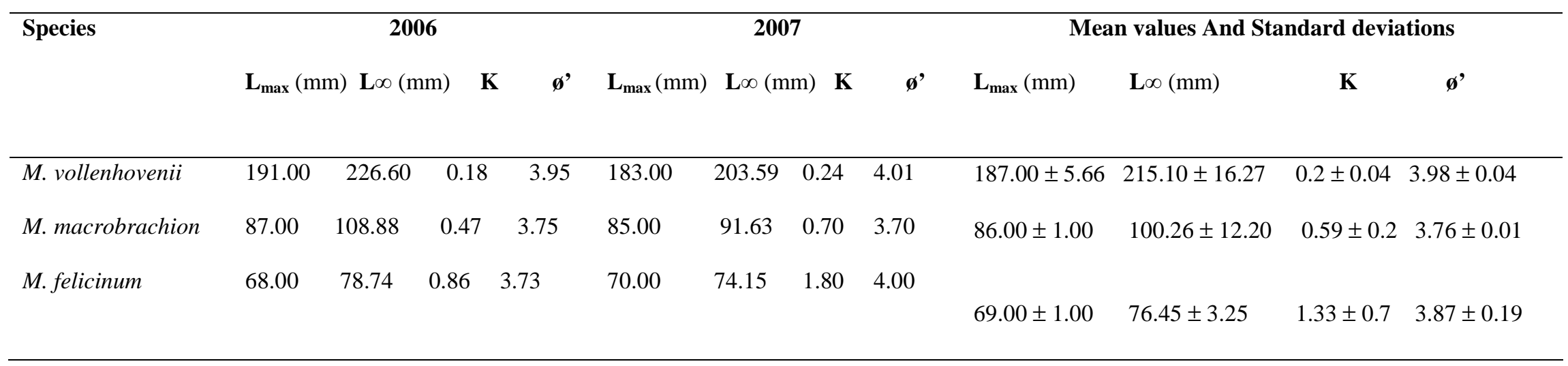

$\mathbf{L}_{\max }=$ Maximum Length

$\mathbf{L} \infty=$ Asymptotic Length

$\mathbf{K}=$ Growth Coefficien

ø' = Growth Performance Index 
reported for $M$. vollenhovenii in Lagos-Lekki Lagoon by Abowheyere et al. (2008). The relatively low $\mathrm{K}$ value of $M$. vollenhovenii in this study could be as a result of the presence of large length classes as indicated by the relatively high maximum and asymptotic lengths. The decline in $\mathrm{K}$ as maximum and asymptotic lengths increase indicates that the growth rate of the prawns decreases with increase in size and age. This agrees with the findings of Ansa and Sikoki (2006) within the populations of benthic bivalves in the Andoni Flat, Niger Delta and Abowheyere (2008) within the populations of Macrobrachium prawns of Lagos-Lekki Lagoon.

The findings in this study, especially the relatively high maximum attainable size recoded for $M$. vollenhovenii as well as the steady growth of the three Macrobrachium species indicate that the environmental conditions in the Lower Ogun River favour growth and development of the prawns. In this regard, it is recommended that the prawns be developed for large-scale aquaculture production. Post-larvae or juveniles of the prawn can be grown either in cages, pens (in the Lower Ogun River) or ponds (within the river vicinity). Growth of the prawns could be enhanced with proper and adequate supplemental feeding. The aquaculture production of the freshwater prawn will undoubtedly reduce pressure on capture fisheries and thereby ensure conservation of the resources and biodiversity.

\section{REFERENCES}

Abohweyere PO. 2008. Length-based Population Dynamics of Prawn (Macrobrachium Species) as resource management tool in Lagos-Lekki Lagoon system. $\mathrm{PhD}$ Thesis, University of Ibadan, Ibadan, Nigeria.

Abohweyere PO, Anyanwu AO, Williams AB. 2008. Recruitment pattern of Macrobrachium vollenhovenii in the Lagos-Lekki Lagoon system, Nigeria. The Zoologist, 6: 55-59.

Abowei JF, Deekae SN, Alison ME, Tawari CC, Ngodigha SA. 2006. A Review of
Shrimp Fisheries in Nigeria. Pre-Joe Publisher: Port Harcourt, Nigeria;10

Ansa EJ, Sikoki FD. 2006. Growth studies of the populations of Benthic Bivalves in the Andoni Flats, Niger Delta, Nigeria. In Proceedings of the $20^{\text {th }}$ Annual Conference of the Fisheries Society of Nigeria. Ansa EJ, Anyanwu PE, Ayonadu BW, Erondu ES, Deekae SN (eds). Port Harcourt, Nigeria; 204-206.

Enin UI. 1995. First estimates of growth, mortality and recruitment parameters of Macrobrachium macrobrachion (Herklots 1851) in the Cross River Estuary, Nigeria. Dana, 11: 29-38.

Etim L, Sankare Y. 1998. Growth and mortality, recruitment and yield of the freshwater shrimps, Macrobrachium vollenhovenii in Fahe Reservoir, Cote d'Ivoire, West Africa. Fish. Res., 38: 211223

Francis A, Sikoki FD. 2006. Growth coefficient of fish species within the Andoni River, Niger Delta, Nigeria and their aquaculture implications. In Proceedings of the $20^{\text {th }}$ Annual Conference of the Fisheries Society of Nigeria. Ansa EJ, Anyanwu PE, Ayonadu BW, Erondu ES, Deekae SN. (eds). Port Harcourt, Nigeria; 322-327.

Gabche CE, Hockey HUP. 1995. Growth and mortality of the giant African prawn,

Macrobrachium vollenhovenii (Herklots: Crustacea: Palaemonidae) in Lobe River, Cameroon: A preliminary evaluation. J. Shellfish. Res. 14(1): 185-190.

Gayanilo FC, Sparre PP, Pauly D. 2005. FISAT II Users' Guide, FAO.http/www.FISAT II.

Marioghae IE. 1982. Note on the Biology and distribution of Macrobrachium vollenhovenii and M. Macrobrachion in the Lagos Lagoon. Rev. Zool Afr., 96(3): 493-508.

Marioghae IE 1990. Studies on fishing methods, gear and marketing of Macrobrachium in the Lagos Area. 
Nigerian Institute for Oceanography and Marine Research. Tech. paper. No 53

Nwosu FM, Wolfi M. 2006. Population dynamics of the giant African river prawn, Macrobrachium vollenhovenii in the Cross River Estuary, Nigeria. West African Journ. of Applied Ecology, 9: 7892.

Powell CB 1983. Fresh and brackish water shrimps of economic importance in the Niger Delta.In Proceedings of the $2^{\text {nd }}$ Annual Conference of the Fisheries Society of Nigeria. Nigeria; 254-285.

Powell DG. 1979. Estimation of mortality and growth parameters from the length frequency in the catch. Rapp. P. $-V$. Reun. CIEM., 175:167-9.
Udolisa RE, Solarin BB. 1979. Design and characteristics of Cast Nets and Gill Nets in the Lagos Lagoon, Nigeria. Nigerian Institute for Oceanography \& Marine Research Occasional Paper, 31: 24.

Wetherall JA. 1986. A new method for estimating growth and mortality parameters from length frequency data. ICLARM Fishbyte, 4(1): 12-14.

Willfhur-Nast J, Rosenthal H, Udo PJ, Nast F. 1993. Laboratory cultivation and experimental studies of salinity effects on larval in the African River prawn, Macrobrachium vollenhovenii. Aquatic Living Resources, 6: 115-137. 